\title{
Correction to: Human T-cell leukaemia virus type 1 associated pulmonary disease: clinical and pathological features of an under-recognised complication of HTLV-1 infection
}

\author{
Lloyd Einsiedel ${ }^{1^{*} \mathbb{D}}$, Fabian Chiong ${ }^{1}$, Hubertus Jersmann ${ }^{2}$ and Graham P. Taylor ${ }^{3}$
}

\section{Correction to: Retrovirology (2021) 18:1 \\ https://doi.org/10.1186/s12977-020-00543-z}

Following publication of the original article [1], several typesetting errors were noted by the authors.

In the final paragraph of the "Epidemiological studies" section a sentence fragment was erroneously duplicated, and is highlighted in bold text below:

However, delays in diagnosis of bronchiectasis are common [60] and the local effects of HTLV-1 mediated pulmonary injury, which will be discussed below, are likely to contribute to risk in this patient group, and the local effects of HTLV-1 mediated pulmonary injury, which will be discussed below, are likely to contribute to risk.

Furthermore, the following sentence in the "Histopathology" section incorrectly referred to Ref. [3] and linked to Ref. [62] instead of [73]. The corrections are given in bold below:

Another Japanese study reported thickening of alveolar septae due to lymphocyte infiltration in tissue obtained by open lung biopsy from thirteen patients

The original article can be found online at https://doi.org/10.1186/s1297 7-020-00543-z.

*Correspondence: Iloyd.einsiedel@nt.gov.au

${ }^{1}$ Department of Medicine, Alice Springs Hospital, Alice Springs, NT 0870, Australia

Full list of author information is available at the end of the article with HTLV-1 who did not have HAM [73]; the major pathological diagnoses recorded were interstitial pneumonias (NSIP, 4; acute interstitial pneumonia, 1 ; lymphocytic interstitial pneumonia, 1; usual interstitial pneumonia, 1) and bronchiolitis (3) with an organizing pneumonia in a single case [73].

Finally, the caption for Fig. 1 erroneously included the sentence "Proposed model for HAPD pathogenesis" and has been removed.

The original article has been updated.

\begin{abstract}
Author details
${ }^{1}$ Department of Medicine, Alice Springs Hospital, Alice Springs, NT 0870, Australia. ${ }^{2}$ Department of Respiratory Medicine, Faculty of Medicine, Royal Adelaide Hospital, Adelaide, Australia. ${ }^{3}$ Department of Infectious Diseases, Faculty of Medicine, Imperial College London, London, UK.
\end{abstract}

Published online: 22 February 2021

\section{Reference}

1. Einsiedel L, Chiong F, Jersmann H, Taylor GP. Human T-cell leukaemia virus type 1 associated pulmonary disease: clinical and pathological features of an under-recognised complication of HTLV-1 infection. Retrovirology. 2021;18:1. https://doi.org/10.1186/s12977-020-00543-z.

\section{Publisher's Note}

Springer Nature remains neutral with regard to jurisdictional claims in published maps and institutional affiliations.

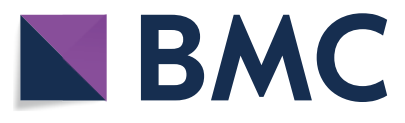

(c) The Author(s) 2021. This article is licensed under a Creative Commons Attribution 4.0 International License, which permits use, sharing, adaptation, distribution and reproduction in any medium or format, as long as you give appropriate credit to the original author(s) and the source, provide a link to the Creative Commons licence, and indicate if changes were made. The images or other third party material in this article are included in the article's Creative Commons licence, unless indicated otherwise in a credit line to the material. If material is not included in the article's Creative Commons licence and your intended use is not permitted by statutory regulation or exceeds the permitted use, you will need to obtain permission directly from the copyright holder. To view a copy of this licence, visit http://creativecommons.org/licenses/by/4.0/. The Creative Commons Public Domain Dedication waiver (http://creativecommons.org/publicdomain/zero/1.0/) applies to the data made available in this article, unless otherwise stated in a credit line to the data. 